Journal of Applied Pharmaceutical Science Vol. 4 (11), pp. 117-127, October, 2014

Available online at http://www.japsonline.com

DOI: $10.7324 / \mathrm{JAPS} .2014 .401021$

ISSN 2231-3354 (cc) BY-NC-SA

\title{
A Systematic Review of Knowledge, Attitude and Practice on Adverse Drug Reactions and Pharmacovigilance among Doctors
}

\author{
Abdullahi Rabiu Abubakar ${ }^{1}$, Nordin Bin Simbak², Mainul Haque ${ }^{3 *}$ \\ ${ }^{1}$ Masters Student, Faculty of Medicine and Health Sciences (FPSK), Universiti Sultan Zainal Abidin (UniSZA), 20400 Kuala Terengganu, Terengganu, \\ Malaysia. ${ }^{2}$ Professor and Dean, Faculty of Medicine and Health Sciences (FPSK), Universiti Sultan Zainal Abidin (UniSZA), Kampus Kota, Jalan Sultan \\ Mahmud 20400, Kuala Terengganu, Malaysia. ${ }^{3}$ Professor and Head of the Unit of Pharmacology, FPSK, UniSZA, 20400 Kuala Terengganu, Terengganu, \\ Malaysia.
}

\section{ARTICLE INFO}

Article history:

Received on: 28/08/2014

Revised on: 16/09/2014

Accepted on: 09/10/2014

Available online: 30/10/2014

Key words:

Adverse Drug Reactions,

Pharmacovigilance,

Knowledge, Attitude,

Practice

\begin{abstract}
Background: Adverse drug reactions (ADRs) have been making headlines because of life threatening issues. ADRs are always underreported and still the major public health problem. Spontaneous reporting system has remained the most significant method for safeguarding patients' lives.

Objectives: Is to examine and analyse the various pharmacovigilance (PV) studies conducted among doctors and to make recommendations for future research.

Study Selection: 32 studies covered from 2004 to 2014 were selected.

Data Sources: Four electronic data-bases including Science-Direct, Springer-Link, PubMed and MEDLINE were used to obtain 129 relevant publications using HotBot, FreeFullPDF, and Google Scholar as search engines.

Data Extraction: Studies conducted on doctors were selected covering research from ten countries.

Inclusion Criteria: Only studies done from 2004 to 2014 were included, KAP studies done on ADRs and pharmacovigilance among doctors were selected.

Exclusion criteria: All studies done before 2004 and studies done on general public KAP were excluded; similarly, studies conducted on healthcare professionals in general were excluded; also studies done on adverse drug event (ADE) reporting were excluded. The study was conducted from April to August, 2014.

Data Synthesis: Knowledge, attitude and practice (KAP) regarding ADRs reporting by doctors were poor. Longitudinal study involving educational intervention and training through workshops and seminars were found to be effective in improving doctors' knowledge and attitude.

Conclusion: There is urgent need to improve knowledge, awareness and practice of doctors on pharmacovigilance. It is imperative for WHO and national pharmacovigilance centres to take proactive measures to curve the menace of ADRs in order to safeguard the patients' lives. The curriculum of all health and health related schools should be restructured with respect to pharmacovigilance without any delay and hesitation.
\end{abstract}

\section{INTRODUCTION}

Worldwide there is increase in public attention on ADRs, this was evidenced by the bill passed by US senate requiring pharmaceutical companies to provide ADRs information to the public (Gray, 1996). Several highly publicized reports and policy makers have urged medical practitioners to put more effort to curtail the problem of ADRs (Kohn et al., 2000; Kachhadiya et al., 2009). The pharmacovigilance study was initiated following the disaster caused by thalidomide in pregnant

\footnotetext{
* Corresponding Author

Prof. Mainul Haque, Professor \& Head, Unit of Pharmacology, Faculty of Medicine and Health Sciences (FPSK), Universiti Sultan Zainal Abidin (UniSZA), 20400 Kuala Terengganu, Terengganu, Malaysia. Email: runurono@gmail.com
}

women in 1961 (WHO, 1969). Pharmacovigilance studies is becoming more important as new drugs are entering the market in jet speed and increase in number of drugs withdrawn because of ADRs (ISDB, 2005; Salam et al., 2013).

It is imperative to acknowledge that currently trial drugs on Ebola virus are now used by West African countries for emergency treatment. Post-marketing safety studies of these drugs have become absolute necessary to avoid any disaster. The major concern is that majority of these drug were developed either in north America or Europe using people from these regions as small scale clinical trials. Hence, there are higher probabilities of ADRs from Ebola medicine due to genetic, cultural, environmental and social differences. 


\section{Definition}

ADRs is any noxious, unintended, and undesired effect of drug that occurs as a result of treatment with drug at a normal doses used in man for diagnosis, prophylaxis, and treatment (WHO, 1972). ADRs can be describe as "an appreciably harmful or unpleasant reaction, resulting from an intervention related to the use of a medicinal product, which predicts hazard from future administration and warrants prevention or specific treatment, or alteration of the dosage regimen, or withdrawal of the product (Edward and Aronson, 2000).

Generally drugs and any other substances that is capable of producing a therapeutic effect can also lead to unwanted or adverse effects, some drugs produce low risk (e.g. hydroxocobalamin or nystatin), whereas others produce high risk (e.g. antineoplastic and immunosuppressant drugs) (Edward and Aronson, 2000). The term "adverse effect" is preferable to other terms such as "side effect" or "toxic effect", side effect occurs via different mechanism and may be dose-related or not. E.g. Sedation due to anti histamines is a side effect, since this action is not associated with the therapeutic effect; similarly anaphylaxis with cephalosporin which is non-dose related is a side effect. A toxic effect is an exaggeration of the desired therapeutic effect which is usually not common at normal doses. E.g. Hypotension due to thiazide diuretics is a toxic effect that occurs by the same mechanism as the therapeutic effect (diuresis). Drug toxicity occurs at a higher dose that is to say toxic effect is always doserelated (Edward and Aronson, 2000).

The terms "adverse reaction" and "adverse effect" are interchangeable, except that an adverse effect is seen from the point of view of the drug, whereas an adverse reaction is seen from the point of view of the patient. However, the terms "adverse effect" and "adverse reaction" must be distinguished from "adverse event". An adverse effect is an adverse outcome that can be attributed to some action of a drug; an adverse event is an adverse outcome that occurs while a patient is taking a drug, but is not or not necessarily attributable to it (Edward and Aronson, 2000).

ADRs are classified into six types (with mnemonics): dose-related (Augmented), non-dose-related (Bizarre), doserelated and time-related (Chronic), time-related (Delayed), withdrawal (End of use), and failure of therapy (Failure) (Edward and Aronson, 2000).

Pharmacovigilance is a science and activities relating to the detection, assessment, understanding and prevention of adverse drug effects (WHO, 2002). Spontaneous reporting system is considered the main mechanism of pharmacovigilance study for gathering information about ADRs after drug is marketed for use by consumers (Edward and Aronson, 2000).

\section{METHODS USED IN PHARMACOVIGILANCE}

In safety study, signals can be generated through four different methods: spontaneous reporting published case reports, cohort studies and post-marketing clinical trials. Now the primary method of collecting post marketing information on the safety of drugs is spontaneous reporting systems (SRS). The main function of SRS is the early detection of signals of new, rare and serious ADRs. A spontaneous reporting system enables physicians and increasingly more often, pharmacists and patients to report suspected ADRs to a pharmacovigilance center (van Grootheest et al., 2004; van Grootheest and de Jong-van, 2004). The major task of the pharmacovigilance center is to collect and analyze the reports and to inform stakeholders of the potential risk when signals of new ADRs arise. Spontaneous reporting is also used by the pharmaceutical industry to collect information about their drugs. By means of a SRS it is possible to monitor all drugs on the market throughout their entire life cycle at a relatively low cost (Harmark and van Grootheest, 2008).

The Pharmacovigilance method used by regulatory authorities is the same with pharmaceutical industries. (1) The possibility of new ADRs is first identified by signal generation processes. This followed by period of signal strengthening and in the second step such signals is subjected to (2) hypothesis testing i.e. processes that determine whether the signal indicating new ADR, or whether it is wrong. The procedure of signal generation is relatively easy if the right systems are in place, the hypothesis testing process is challenging and often time consuming and may require variety of approaches (Talbot and Nilsson, 1998).

\section{The specific objectives of Pharmacovigilance}

i. To improve patient care and safety in relation to the use of medicines and all medical and paramedical interventions.

ii. To improve public health and safety in relation to the use of medicines.

iii. To contribute to the assessment of benefit, harm, effectiveness and risk of medicines, encouraging their safe, rational and more cost-effective use.

iv. To promote understanding, education and clinical training in pharmacovigilance and its effective communication to the public (Talbot and Nilsson, 1998).

\section{AIM OF THE STUDY}

i. To investigate previous researches conducted on KAP of doctors on ADR reporting.

ii. To relate the outcome obtained by various studies.

iii. To find out the gaps identified by the various researchers and make recommendations for further research.

\section{Operational Definitions}

Knowledge: Means theoretical or practical understanding of the subject matter.

Attitude: A predisposition or a tendency to respond positively or negatively towards a certain idea, object, person, or situation.

Practice: Application of knowledge or practical approach to the subject matter. 
Table 1: Summary of the Reviewed Articles.

\begin{tabular}{|c|c|c|c|c|c|c|c|}
\hline $\mathbf{S} / \mathbf{N}$ & $\underset{7}{\bar{J}}$ & 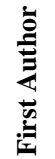 & 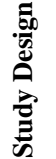 & 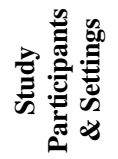 & 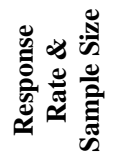 & 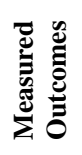 & 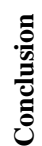 \\
\hline
\end{tabular}

\begin{tabular}{|c|c|c|c|c|c|c|c|c|}
\hline 1 & 2005 & Herdeiro, MT & $\begin{array}{l}\text { Case-Control } \\
\text { self- } \\
\text { completed } \\
\text { questionnaire }\end{array}$ & $\begin{array}{l}\text { Random sample } \\
\text { of physicians in } \\
\text { Northern Region } \\
\text { of Portugal }\end{array}$ & $\begin{array}{l}54.3 \% \text {, } \\
\text { Experiment }(n=88), \\
\text { Control }(n=771), \\
\text { Total }(n=859)\end{array}$ & $\begin{array}{l}\text { Knowledge } \\
\text { and attitude }\end{array}$ & $\begin{array}{l}\text { The study revealed } \\
\text { that medical } \\
\text { practitioners' } \\
\text { attitude was } \\
\text { strongly associated } \\
\text { with under- } \\
\text { reporting of ADRs }\end{array}$ & $\begin{array}{l}\text { Under-reporting could } \\
\text { be greatly reduced by } \\
\text { changing the attitude } \\
\text { of Medical } \\
\text { practitioners }\end{array}$ \\
\hline 2 & 2006 & Backstrom, M & $\begin{array}{l}\text { Interventional } \\
\text { Case-Control } \\
\text { self- } \\
\text { completed } \\
\text { questionnaire }\end{array}$ & $\begin{array}{l}\text { Random sample } \\
\text { of physicians in } \\
\text { Health Care } \\
\text { Centres from } \\
\text { Two Districts of } \\
\text { Northern Sweden } \\
\end{array}$ & $66 \%,(\mathrm{n}=540)$ & $\begin{array}{l}\text { Increase in } \\
\text { attitude and } \\
\text { practice with } \\
\text { economic } \\
\text { inducement }\end{array}$ & $\begin{array}{l}\text { Economic } \\
\text { inducement had } \\
\text { increase the ADRs } \\
\text { reporting rate }\end{array}$ & $\begin{array}{l}\text { There is need to } \\
\text { investigate the impact } \\
\text { of incentives in ADRs } \\
\text { monitoring }\end{array}$ \\
\hline 3 & 2006 & Chatterjee, S & $\begin{array}{l}\text { Cross } \\
\text { Sectional self } \\
\text {-completed } \\
\text { questionnaire }\end{array}$ & $\begin{array}{l}\text { Physicians from } \\
\text { Eastern India }\end{array}$ & $64.2 \%,(n=215)$ & $\begin{array}{l}\text { Knowledge, } \\
\text { attitude and } \\
\text { practice }\end{array}$ & $\begin{array}{l}\text { The doctors had } \\
\text { good knowledge } \\
\text { but poor attitude } \\
\text { and practice }\end{array}$ & $\begin{array}{l}\text { There is need to } \\
\text { include } \\
\text { pharmacovigilance } \\
\text { training in } \\
\text { undergraduate } \\
\text { curriculum }\end{array}$ \\
\hline 4 & 2008 & Fracas, A & $\begin{array}{l}\text { Cross } \\
\text { Sectional self } \\
\text {-completed } \\
\text { questionnaire } \\
\end{array}$ & $\begin{array}{l}\text { Doctors from } \\
\text { Hospitals in } \\
\text { Cluj-Napoca, } \\
\text { Romania }\end{array}$ & $86 \%,(n=200)$ & $\begin{array}{l}\text { Knowledge, } \\
\text { attitude and } \\
\text { practice }\end{array}$ & $\begin{array}{l}\text { Doctors had poor } \\
\text { knowledge, } \\
\text { attitude and } \\
\text { practice }\end{array}$ & $\begin{array}{l}\text { It is crucial to increase } \\
\text { doctors awareness on } \\
\text { ADR reporting }\end{array}$ \\
\hline 5 & 2009 & Passier, A & $\begin{array}{l}\text { Cross } \\
\text { Sectional self } \\
\text {-completed } \\
\text { questionnaire }\end{array}$ & $\begin{array}{l}\text { Random sample } \\
\text { of General } \\
\text { Medical } \\
\text { Practitioners } \\
\text { (GPs), } \\
\text { Netherlands }\end{array}$ & $\begin{array}{l}47 \%, \text { Activer- } \\
\text { eporters }(n=500), \\
\text { Non-reporters }(1000) \text {, } \\
\text { Total }(n=1500)\end{array}$ & $\begin{array}{l}\text { Knowledge } \\
\text { and attitude }\end{array}$ & $\begin{array}{l}\text { Active reporters } \\
\text { had better } \\
\text { knowledge and } \\
\text { attitude than Nson- } \\
\text { reporters }\end{array}$ & $\begin{array}{l}\text { There is need to } \\
\text { increase } \\
\text { communication } \\
\text { between GPs and both } \\
\text { pharmacist and } \\
\text { patients }\end{array}$ \\
\hline 6 & 2009 & Ramesh, M & $\begin{array}{l}\text { Cross } \\
\text { Sectional self } \\
\text {-completed } \\
\text { questionnaire }\end{array}$ & $\begin{array}{l}\text { Random sample } \\
\text { of Doctors of } \\
\text { Jagadguru, } \\
\text { Basappa and } \\
\text { Holdsworth } \\
\text { Hospital Mysore, } \\
\text { India } \\
\end{array}$ & $88 \%,(n=110)$ & $\begin{array}{l}\text { Attitude and } \\
\text { perception }\end{array}$ & $\begin{array}{l}\text { The doctors had } \\
\text { good knowledge } \\
\text { and attitude but } \\
\text { their practice is in } \\
\text { adequate. }\end{array}$ & $\begin{array}{l}\text { Pharmacist should be } \\
\text { included in ADRs } \\
\text { reporting }\end{array}$ \\
\hline 7 & 2009 & Oshikoya, KA & $\begin{array}{l}\text { Cross } \\
\text { Sectional self } \\
\text {-completed } \\
\text { questionnaire }\end{array}$ & $\begin{array}{l}\text { Cluster sample of } \\
\text { Doctors in Lagos } \\
\text { State University } \\
\text { Teaching } \\
\text { Hospital, Nigeria }\end{array}$ & $82.5 \%,(n=99)$ & Perception & $\begin{array}{l}\text { Doctors had } \\
\text { inadequate } \\
\text { knowledge and } \\
\text { awareness on } \\
\text { ADRs reporting }\end{array}$ & $\begin{array}{l}\text { All doctors should } \\
\text { undergo continuous } \\
\text { education and training } \\
\text { on ADRs reporting }\end{array}$ \\
\hline 8 & 2009 & Tabali, M & $\begin{array}{l}\text { Longitudinal } \\
\text { study, } \\
\text { Questionnaire } \\
\text { and face to } \\
\text { face } \\
\text { interview }\end{array}$ & $\begin{array}{l}\text { Random sample } \\
\text { of Physicians } \\
\text { from } 12 \text { states, } \\
\text { Germany }\end{array}$ & $100 \%,(\mathrm{n}=38)$ & $\begin{array}{l}\text { Changes in } \\
\text { ADRs } \\
\text { reporting rate }\end{array}$ & $\begin{array}{l}\text { Educational } \\
\text { intervention had } \\
\text { increase } \\
\text { physicians } \\
\text { awareness on } \\
\text { ADR reporting }\end{array}$ & $\begin{array}{l}\text { There is need to } \\
\text { increase awareness and } \\
\text { educational } \\
\text { intervention in } \\
\text { pharmacovigilance }\end{array}$ \\
\hline 9 & 2011 & Awodele, $\mathrm{O}$ & $\begin{array}{l}\text { Cross } \\
\text { Sectional self } \\
\text {-completed } \\
\text { questionnaire }\end{array}$ & $\begin{array}{l}\text { Doctors in } \\
\text { private hospitals } \\
\text { in Lagos West } \\
\text { Senatorial } \\
\text { District, Nigeria }\end{array}$ & $93 \%,(n=270)$ & $\begin{array}{l}\text { Knowledge } \\
\text { and practice }\end{array}$ & $\begin{array}{l}\text { The doctors } \\
\text { working in a } \\
\text { private hospitals } \\
\text { had good } \\
\text { knowledge but } \\
\text { poor practice }\end{array}$ & $\begin{array}{l}\text { There is need for } \\
\text { training for doctors } \\
\text { working in a private } \\
\text { hospitals }\end{array}$ \\
\hline 10 & 2011 & Chopra, D & $\begin{array}{l}\text { Cross } \\
\text { Sectional self } \\
\text {-completed } \\
\text { questionnaire }\end{array}$ & $\begin{array}{l}\text { Doctors of Lady } \\
\text { Hardinge } \\
\text { Medical College } \\
\text { and associated } \\
\text { Hospital }\end{array}$ & $100 \%,(n=100)$ & $\begin{array}{l}\text { Knowledge, } \\
\text { attitude and } \\
\text { practice }\end{array}$ & $\begin{array}{l}\text { The doctors had } \\
\text { inadequate } \\
\text { knowledge and } \\
\text { poor practice }\end{array}$ & $\begin{array}{l}\text { There is need for more } \\
\text { awareness and } \\
\text { educational } \\
\text { intervention }\end{array}$ \\
\hline 11 & 2011 & Bello, SO & $\begin{array}{l}\text { Cross } \\
\text { Sectional self } \\
\text {-completed } \\
\text { questionnaire }\end{array}$ & $\begin{array}{l}\text { Convenient } \\
\text { sample of } \\
\text { Physicians from } \\
\text { four government } \\
\text { Hospitals in } \\
\text { Sokoto, Nigeria } \\
\end{array}$ & $100 \%,(\mathrm{n}=61)$ & $\begin{array}{l}\text { Knowledge } \\
\text { and attitude }\end{array}$ & $\begin{array}{l}\text { Doctors had poor } \\
\text { knowledge, } \\
\text { attitude and } \\
\text { practice }\end{array}$ & $\begin{array}{l}\text { There is need for } \\
\text { awareness campaign } \\
\text { for physicians and } \\
\text { patients }\end{array}$ \\
\hline
\end{tabular}




\begin{tabular}{|c|c|c|c|c|c|c|c|c|}
\hline 12 & 2011 & Gupta, P & $\begin{array}{l}\text { Cross Sectional } \\
\text { self -completed } \\
\text { questionnaire }\end{array}$ & $\begin{array}{l}\text { Convenient sample of } \\
\text { Resident doctors of B.J } \\
\text { and Seth G.S Medical } \\
\text { Colleges Mumbai, } \\
\text { India }\end{array}$ & $\begin{array}{l}77.2 \% \\
(\mathrm{n}= \\
407)\end{array}$ & $\begin{array}{l}\text { Knowledge, } \\
\text { attitude and } \\
\text { perception }\end{array}$ & $\begin{array}{l}\text { Knowledge, attitude } \\
\text { and practice of } \\
\text { doctors were deficient }\end{array}$ & $\begin{array}{l}\text { There is need for more } \\
\text { awareness and educational } \\
\text { intervention }\end{array}$ \\
\hline 13 & 2011 & Desai, CK & $\begin{array}{l}\text { Cross Sectional } \\
\text { self -completed } \\
\text { questionnaire }\end{array}$ & $\begin{array}{l}\text { Prescribers of Tertiary } \\
\text { Care Hospital of B.J } \\
\text { Medical College } \\
\text { Ahmedabad, India } \\
\end{array}$ & $\begin{array}{l}61 \%,(\mathrm{n} \\
=436)\end{array}$ & $\begin{array}{l}\text { Knowledge, } \\
\text { attitude and } \\
\text { practice }\end{array}$ & $\begin{array}{l}\text { The prescribers } \\
\text { knowledge and } \\
\text { practice were poor } \\
\text { but had good attitude }\end{array}$ & $\begin{array}{l}\text { The reporting procedure } \\
\text { should be made easy and } \\
\text { convenient for doctors }\end{array}$ \\
\hline 14 & 2012 & Kharkar, M & $\begin{array}{l}\text { Cross Sectional } \\
\text { self -completed } \\
\text { questionnaire }\end{array}$ & $\begin{array}{l}\text { Medical practitioners } \\
\text { from four different } \\
\text { zones, India }\end{array}$ & $\begin{array}{l}73 \%,(\mathrm{n} \\
=1200)\end{array}$ & $\begin{array}{l}\text { Knowledge, } \\
\text { attitude and } \\
\text { practice }\end{array}$ & $\begin{array}{l}\text { The Medical } \\
\text { practitioners had } \\
\text { good knowledge and } \\
\text { attitude but poor } \\
\text { practice }\end{array}$ & $\begin{array}{l}\text { There is need to include } \\
\text { pharmacovigilance training } \\
\text { in undergraduate } \\
\text { curriculum }\end{array}$ \\
\hline 15 & 2012 & Rishi, RK ${ }^{1}$ & $\begin{array}{l}\text { Cross Sectional } \\
\text { self-completed } \\
\text { questionnaire }\end{array}$ & $\begin{array}{l}\text { Random sample of } \\
\text { Medical practitioners } \\
\text { from } 15 \text { India states }\end{array}$ & $\begin{array}{l}100 \% \\
(\mathrm{n}= \\
100)\end{array}$ & $\begin{array}{l}\text { Opinion and } \\
\text { attitude }\end{array}$ & $\begin{array}{l}\text { The doctors had good } \\
\text { attitude and opinion } \\
\text { but poor practice }\end{array}$ & $\begin{array}{l}\text { There is need for } \\
\text { workshops and conferences } \\
\text { with continuous medical } \\
\text { education for physicians on } \\
\text { ADRs reporting }\end{array}$ \\
\hline 16 & 2012 & Rishi, RK ${ }^{2}$ & $\begin{array}{l}\text { Cross Sectional } \\
\text { self -completed } \\
\text { questionnaire }\end{array}$ & $\begin{array}{l}\text { Random sample of } \\
\text { Medical practitioners } \\
\text { from } 15 \text { India states }\end{array}$ & $\begin{array}{l}100 \% \\
(\mathrm{n}= \\
100)\end{array}$ & $\begin{array}{l}\text { Knowledge, } \\
\text { attitude and } \\
\text { practice }\end{array}$ & $\begin{array}{l}\text { The physicians had } \\
\text { poor knowledge and } \\
\text { attitude }\end{array}$ & $\begin{array}{l}\text { There is need for } \\
\text { introducing use of } \\
\text { information technology in } \\
\text { pharmacovigilance and } \\
\text { direct patient reporting }\end{array}$ \\
\hline 17 & 2012 & $\begin{array}{l}\text { Pimpalkhute, } \\
\text { SA }\end{array}$ & $\begin{array}{l}\text { Cross Sectional } \\
\text { self -completed } \\
\text { questionnaire }\end{array}$ & $\begin{array}{l}\text { Convenient sample of } \\
\text { Resident doctors of } \\
\text { Government Medical } \\
\text { college, Nagpur, India }\end{array}$ & $\begin{array}{l}93.3 \% \\
(\mathrm{n}= \\
90)\end{array}$ & $\begin{array}{l}\text { Knowledge } \\
\text { and attitude }\end{array}$ & $\begin{array}{l}\text { The doctors had poor } \\
\text { knowledge, attitude } \\
\text { and practice }\end{array}$ & $\begin{array}{l}\text { There is need to increase } \\
\text { doctors awareness on ADRs } \\
\text { reporting }\end{array}$ \\
\hline 18 & 2012 & John, L J & $\begin{array}{l}\text { Cross Sectional } \\
\text { self -completed } \\
\text { questionnaire }\end{array}$ & $\begin{array}{l}\text { Convenient sample of } \\
\text { Doctors working in a } \\
\text { Tertiary Care Hospital, } \\
\text { United Arab Emirate }\end{array}$ & $\begin{array}{l}76 \%,(\mathrm{n} \\
=55)\end{array}$ & $\begin{array}{l}\text { Knowledge } \\
\text { and practice }\end{array}$ & $\begin{array}{l}\text { The doctors had poor } \\
\text { Knowledge, attitude } \\
\text { and practice }\end{array}$ & $\begin{array}{l}\text { There is need to initiate } \\
\text { workshops and training } \\
\text { programs on } \\
\text { pharmacovigilance for } \\
\text { doctors }\end{array}$ \\
\hline 19 & 2012 & Upadhyaya, P & $\begin{array}{l}\text { Cross Sectional } \\
\text { self -completed } \\
\text { questionnaire }\end{array}$ & $\begin{array}{l}\text { Cluster sample of } \\
\text { Postgraduate doctors } \\
\text { working in a Tertiary } \\
\text { Care Hospital, } \\
\text { Mahatma Gandhi } \\
\text { Medical College, } \\
\text { Jaipur, India } \\
\end{array}$ & $\begin{array}{l}100 \% \\
(\mathrm{n}= \\
50)\end{array}$ & $\begin{array}{l}\text { Knowledge } \\
\text { and practice }\end{array}$ & $\begin{array}{l}\text { Knowledge and } \\
\text { practice was poor }\end{array}$ & $\begin{array}{l}\text { There is need to maintain } \\
\text { close relationship between } \\
\text { physicians and } \\
\text { pharmacovigilance center }\end{array}$ \\
\hline 20 & 2012 & Kamtane, RA & $\begin{array}{l}\text { Cross sectional- } \\
\text { Observational } \\
\text { Questionnaire } \\
\text { based }\end{array}$ & $\begin{array}{l}\text { Random sample of } \\
\text { doctors working in } \\
\text { different fields, } \\
\text { Hyderabad India }\end{array}$ & $\begin{array}{l}78.3 \% \\
(\mathrm{n}= \\
120)\end{array}$ & $\begin{array}{l}\text { Knowledge, } \\
\text { attitude and } \\
\text { perception }\end{array}$ & $\begin{array}{l}\text { The physicians had } \\
\text { poor knowledge but } \\
\text { good attitude and } \\
\text { perception }\end{array}$ & $\begin{array}{l}\text { ADRs reporting by } \\
\text { Pharmacist, Nurses and } \\
\text { even Patients should be } \\
\text { encouraged }\end{array}$ \\
\hline 21 & 2013 & Shailesh, N & $\begin{array}{l}\text { Longitudinal } \\
\text { self -completed } \\
\text { questionnaire }\end{array}$ & $\begin{array}{l}\text { Convenient sample of } \\
\text { Graduate doctors of } \\
\text { Mahatma Gandhi } \\
\text { Institute of Medical } \\
\text { Sciences Maharashtra, } \\
\text { India }\end{array}$ & $\begin{array}{l}100 \% \\
(\mathrm{n}= \\
65)\end{array}$ & $\begin{array}{l}\text { Knowledge, } \\
\text { attitude and } \\
\text { practice }\end{array}$ & $\begin{array}{l}\text { Medical graduates } \\
\text { had poor knowledge } \\
\text { and practice but good } \\
\text { attitude. The } \\
\text { knowledge improved } \\
\text { after intervention }\end{array}$ & $\begin{array}{l}\text { There is need for medical } \\
\text { graduates to undergo } \\
\text { continuous education and } \\
\text { training on ADRs reporting }\end{array}$ \\
\hline 22 & 2013 & Adhikary, J & $\begin{array}{l}\text { Cross Sectional } \\
\text { self -completed } \\
\text { questionnaire }\end{array}$ & $\begin{array}{l}\text { Cluster sample of } \\
\text { Physicians of } \\
\text { Rajajeswari Medical } \\
\text { college and Hospital, } \\
\text { Bangalore, India } \\
\end{array}$ & $\begin{array}{l}70.9 \% \\
(\mathrm{n}= \\
189)\end{array}$ & $\begin{array}{l}\text { Knowledge, } \\
\text { attitude and } \\
\text { practice }\end{array}$ & $\begin{array}{l}\text { The physicians } \\
\text { limited knowledge } \\
\text { and practice but better } \\
\text { attitude }\end{array}$ & $\begin{array}{l}\text { It is desirable to initiate } \\
\text { workshops and training } \\
\text { programs on ADR reporting }\end{array}$ \\
\hline 23 & 2013 & Paveliu, MS & $\begin{array}{l}\text { Questionnaire } \\
\text { and face to face } \\
\text { interview }\end{array}$ & $\begin{array}{l}\text { Random sample of } \\
\text { Physician working in } \\
\text { Southern Romania }\end{array}$ & $\begin{array}{l}100 \% \\
(\mathrm{n}= \\
532)\end{array}$ & Perception & $\begin{array}{l}\text { The doctors had poor } \\
\text { knowledge and } \\
\text { practice but good } \\
\text { attitude }\end{array}$ & $\begin{array}{l}\text { Pharmacovigilance study } \\
\text { should be included in the } \\
\text { curriculum of training } \\
\text { residents physicians }\end{array}$ \\
\hline 24 & 2013 & Adedeji, WA & $\begin{array}{l}\text { Cross Sectional } \\
\text { self -completed } \\
\text { questionnaire }\end{array}$ & $\begin{array}{l}\text { Cluster sample Doctors } \\
\text { Ladoke Akintola } \\
\text { University of } \\
\text { Technology, Oyo, } \\
\text { Nigeria }\end{array}$ & $\begin{array}{l}100 \%, \\
(\mathrm{n}= \\
35)\end{array}$ & $\begin{array}{l}\text { Attitude and } \\
\text { practice }\end{array}$ & $\begin{array}{l}\text { The doctors had good } \\
\text { knowledge but } \\
\text { attitude and practice }\end{array}$ & $\begin{array}{l}\text { There is need to establish } \\
\text { pharmacovigilance } \\
\text { committee in the hospital }\end{array}$ \\
\hline 25 & 2013 & Agarwal, R & $\begin{array}{l}\text { Cross Sectional } \\
\text { self -completed } \\
\text { questionnaire }\end{array}$ & $\begin{array}{l}\text { Simple random sample } \\
\text { of Private practitioners } \\
\text { of Klang Valley, } \\
\text { Malaysia }\end{array}$ & $\begin{array}{l}61 \%,(\mathrm{n} \\
=238)\end{array}$ & $\begin{array}{l}\text { Knowledge, } \\
\text { attitude and } \\
\text { practice }\end{array}$ & $\begin{array}{l}\text { Knowledge, attitude } \\
\text { and practice of } \\
\text { doctors was } \\
\text { inadequate }\end{array}$ & $\begin{array}{l}\text { There is need for teaching } \\
\text { pharmacovigilance in detail } \\
\text { in undergraduate } \\
\text { curriculum }\end{array}$ \\
\hline 26 & 2013 & Khan, SA & $\begin{array}{l}\text { Cross sectional } \\
\text { self-completed } \\
\text { questionnaire }\end{array}$ & $\begin{array}{l}\text { Cluster sample of } \\
\text { Doctors in Teaching } \\
\text { Hospital India }\end{array}$ & $\begin{array}{l}62.9 \% \\
(\mathrm{n}= \\
108)\end{array}$ & $\begin{array}{l}\text { Knowledge } \\
\text { and attitude }\end{array}$ & $\begin{array}{l}\text { Knowledge, attitude } \\
\text { and practice of } \\
\text { doctors were poor }\end{array}$ & $\begin{array}{l}\text { There is urgent need for } \\
\text { knowledge intervention to } \\
\text { improve pharmacovigilance } \\
\text { and enhance patient safety }\end{array}$ \\
\hline
\end{tabular}




\begin{tabular}{|c|c|c|c|c|c|c|c|}
\hline 272013 & $\begin{array}{l}\text { Thomas, } \\
\text { TM }\end{array}$ & $\begin{array}{l}\text { Cross sectional } \\
\text { self-completed } \\
\text { questionnaire }\end{array}$ & $\begin{array}{l}\text { Doctors of Tertiary } \\
\text { Health Centers in } \\
\text { Mangalore, Southern } \\
\text { India }\end{array}$ & $100 \%,(\mathrm{n}=60)$ & $\begin{array}{l}\text { Knowledge, } \\
\text { attitude and } \\
\text { practice }\end{array}$ & $\begin{array}{l}\text { The Knowledge and } \\
\text { attitude of doctors were } \\
\text { good but the practice } \\
\text { level was poor }\end{array}$ & $\begin{array}{l}\text { There is need for more } \\
\text { awareness on ADRs reporting } \\
\text { through continuous education } \\
\text { and training }\end{array}$ \\
\hline $28 \quad 2013$ & $\begin{array}{l}\text { Sanghavi, } \\
\text { DR }\end{array}$ & $\begin{array}{l}\text { Longitudinal- self } \\
\text {-completed } \\
\text { questionnaire }\end{array}$ & $\begin{array}{l}\text { Cluster sampling of } \\
\text { Doctors in Bharati } \\
\text { Teaching Hospital, } \\
\text { Pune, India }\end{array}$ & $36.4 \%,(n=220)$ & $\begin{array}{l}\text { Knowledge, } \\
\text { attitude and } \\
\text { practice }\end{array}$ & $\begin{array}{l}\text { The physician had good } \\
\text { attitude but poor } \\
\text { knowledge and practice }\end{array}$ & $\begin{array}{l}\text { The quality of ADR reporting } \\
\text { can be improved via } \\
\text { education and training of the } \\
\text { clinicians }\end{array}$ \\
\hline $29 \quad 2014$ & Iffat, W & $\begin{array}{l}\text { Cross sectional } \\
\text { self-completed } \\
\text { questionnaire }\end{array}$ & $\begin{array}{l}\text { Random sample of } \\
\text { Doctors in public and } \\
\text { private hospitals and } \\
\text { clinics in Karachi, } \\
\text { Pakistan. }\end{array}$ & $40.9 \%,(n=550)$ & $\begin{array}{l}\text { Knowledge } \\
\text { and attitude }\end{array}$ & $\begin{array}{l}\text { The Doctors had good } \\
\text { knowledge of ADRs } \\
\text { reporting but poor } \\
\text { attitude. }\end{array}$ & $\begin{array}{l}\text { There is need for continuous } \\
\text { education and training for } \\
\text { physicians about } \\
\text { pharmacovigilance }\end{array}$ \\
\hline $30 \quad 2014$ & Bisht, $\mathrm{M}$ & $\begin{array}{l}\text { Case control self- } \\
\text { completed } \\
\text { questionnaire }\end{array}$ & $\begin{array}{l}\text { Convenient sample of } \\
\text { Doctors of Tertiary } \\
\text { Care Teaching Hospital, } \\
\text { Uttarakhand, India }\end{array}$ & $\begin{array}{l}80 \%, \text { Doctors that } \\
\text { attended lectures } \\
(\mathrm{n}=125), \text { Doctors } \\
\text { that didn't attend } \\
(\mathrm{n}=125)\end{array}$ & $\begin{array}{l}\text { Knowledge, } \\
\text { attitude and } \\
\text { practice }\end{array}$ & $\begin{array}{l}\text { After the educational } \\
\text { intervention, the doctors } \\
\text { knowledge and attitude } \\
\text { improved but poor } \\
\text { practice }\end{array}$ & $\begin{array}{l}\text { Strategies should be } \\
\text { employed to increase doctors } \\
\text { awareness and reporting } \\
\text { culture }\end{array}$ \\
\hline 312014 & Aithal, S & $\begin{array}{l}\text { Cross sectional } \\
\text { self-completed } \\
\text { questionnaire }\end{array}$ & $\begin{array}{l}\text { Convenient sample of } \\
\text { Doctors of Tertiary } \\
\text { Health care Hospital, } \\
\text { Davangere, Karnataka, } \\
\text { India }\end{array}$ & $39 \%,(n=42)$ & $\begin{array}{l}\text { Knowledge } \\
\text { and attitude }\end{array}$ & $\begin{array}{l}\text { The doctors had poor } \\
\text { knowledge but good } \\
\text { attitude and practice }\end{array}$ & $\begin{array}{l}\text { There is need to address } \\
\text { factors discouraging doctors } \\
\text { from reporting ADRs }\end{array}$ \\
\hline $32 \quad 2014$ & Kiran, L J & $\begin{array}{l}\text { Cross sectional } \\
\text { self-completed } \\
\text { questionnaire }\end{array}$ & $\begin{array}{l}\text { Cluster sample of } \\
\text { Clinicians of Teaching } \\
\text { Hospital, South } \\
\text { Karnataka, India }\end{array}$ & $80 \%,(n=150)$ & $\begin{array}{l}\text { Knowledge, } \\
\text { attitude and } \\
\text { practice }\end{array}$ & $\begin{array}{l}\text { The clinicians had poor } \\
\text { knowledge and practice } \\
\text { but good attitude }\end{array}$ & $\begin{array}{l}\text { There is need for more } \\
\text { awareness and educational } \\
\text { intervention }\end{array}$ \\
\hline
\end{tabular}

\section{MATERIALS AND METHODS}

This article focused on researches done on ADRs and PV, it was also based on WHO definition of ADRs excluding therapeutic failure, overdose, errors in drug administration, and noncompliance (Lazarou et al., 1998; Patel and Ganguly, 2010). ADRs are caused by inherent properties of the drug (non-preventable); therefore, they are most relevant to this study (Phillips et al., 2001).

Study Selection: Studies conducted from 2004 to 2014 were selected because they were considered most recent and will portray the current picture of what is obtainable in countries where the various researches was conducted.

Data Sources: Four electronic data bases including ScienceDirect, Springer-Link, PubMed and MEDLINE were used to obtain 129 relevant publications on knowledge, attitude and practice on ADRs and PV among doctors using HotBot, FreeFullPDF and Google scholar as search engines. The search terms included: ADRs, PV, ADRs reporting, drug surveillance, PV study, survey on ADRs reporting, spontaneous reporting of ADRs, ADR signal detection combined with the following: doctors, medical practitioners, awareness, knowledge, attitude and practice.

Inclusion Criteria:Only studies done from 2004 to 2014 were included, KAP studies done on ADRs and PV among doctors were selected.
Exclusion criteria: All studies done before 2004 and studies done on general public KAP were excluded; studies conducted on healthcare professionals in general were excluded; also studies done on adverse drug event (ADE) reporting were excluded. The references of all the initial articles that met the inclusion criteria were cross-checked, and more relevant articles were retrieved and included.

Data Extraction: Researches from several counties were selected and about ten countries were covered in this article. Finally, 32 articles were chosen, examined and analysed; areas that require further investigation were also identified. The various research findings were correlated and based on the various outcome recommendations and conclusion was made. The article was reviewed by the first two authors.

\section{RESULT}

\section{Description of the Articles Included}

Total of 29 articles obtained from different countries that met the inclusion criteria was reviewed. Nineteen articles were published in India (Kiran et al., 2014; Aithal et al., 2014; Bisht et al., 2014; Sabghavi et al., 2013; Adhikary et al., 2013; Shailesh et al., 2013; Thomas et al., 2013; Khan et al., 2013; Kamtane and Jayawardhani, 2012; Upadhyaya et al., 2012; Pimpalkhute et al., 2012; Rishi et al., 2012a; Rishi et al., 2012b; Kharkar and Bowalekar, 2012; Desai et al., 2011; Gupta and Udupa, 2011; Chopra et al., 2011; Ramesh and Parthasarathi, 2009; Chatterjee et al., 2006); four studies from Nigeria (Adedeji et al., 2013; Bello 
and Umar, 2011; Awodele et al., 2011; Oshikoya and Awobusuyi, 2009); two from Romania (Paveliu et al., 2013; Farcas et al., 2008), one from Pakistan (Iffat et al., 2014), one from Malaysia (Agarwal et al., 2013), one UAE (John et al., 2012), one Germany (Tabali et al., 2009), one from Netherland (Passier et al., 2009), one from Sweden (Backstrom and Mjorndal, 2006) and finally one from Portugal (Herdeiro et al., 2005). Two surveys were longitudinal studies (Tabali et al., 2009; Sanghavi et al., 2013); two studies (Paveliu et al., 2013; Tabali et al., 2009) used face to face interview in addition to questionnaire as a research tool; the remaining surveys were cross-sectional questionnaire based studies. The topic ADR reporting or PV by doctors was discussed in all the articles reviewed. The terms 'physicians', 'medical practitioners', 'doctors' were used by all the authors and a times interchangeably because they were all considered to mean the same thing.

\section{Doctors' Knowledge towards ADR Reporting}

According to the various article reviewed, doctors' knowledge was assessed based on five main parameters, namely: Definition or awareness on ADR and PV; who is to report ADR and location of ADR reporting centre; purpose of reporting; as well as awareness on reporting procedure and reporting forms.

\section{Definition or Awareness on ADR and PV}

The result of the various researches indicated poor knowledge of ADR reporting by doctors even though many of them were aware of or could define ADR and PV. Study conducted in Pakistan reported that $88 \%$ of the medical practitioners were aware of ADR (Iffat et al., 2014), also positive findings were obtained in a study from India $52.3 \%$ (Thomas et al., 2013), 57\% ( Shailesh et al., 2013) and 66\% (Chopra et al., 2011). In another survey carried out in Nigeria $82.9 \%$ of doctors were aware of PV (Awodele et al., 2011), also in India 58\% (Kharkar and Bowalekar, 2012), 69.1\% (Khan et al., 2013), and $64.3 \%$ (Pimpalkhute, 2012). In contrast, study conducted in Romania revealed that only $22.6 \%$ of physicians were aware of PV (Paveliu et al., 2013), similar findings was obtained in a study from Pakistan $31.5 \%$ (Iffat et al., 2014); also in a study from India $54.4 \%$ of physicians were not aware of PV (Kantame and Jayawardhani, 2012).

\section{Who is to Report ADR and Location of ADR Reporting Centre?}

Doctors' in most cases gave less priority to the contribution of other health workers in ADR reporting, also their awareness on ADR reporting centre was generally low. Survey carried out in Nigeria reported that $89 \%$ of respondents felt that doctors are most qualified to report ADR (Oshikoya and Awobusuyi, 2009), 59\% (Awodele et al., 2011), similar outcome was obtained in India 95\% (Sanghavi et al., 2013), 95.7\% (Kamtane and Jayawardhani, 2012), 97\% (Khan et al., 2013) and Pakistan 64\% (Iffat et al., 2014).
Regarding the ADR reporting centre, a research conducted in Pakistan showed that only $15.5 \%$ of physicians know the ADR reporting centre (Iffat et al., 2014), similar findings were obtained from study in India $11.7 \%$ (Thomas et al., 2013), 15\% (Kiran et al., 2014), 25\% (Shailesh et al., 2013), 30\% (Chopra et al, 2011), and 47.5\% (Kharkar and Bowalekar, 2012), and in Nigeria 40.4\% (Oshikoya and Awobusuyi, 2009). Another research conducted in Malaysia revealed that $57 \%$ of doctors do not know where to report ADRs (Agarwal et al., 2013), similar result was found in India 43\% (Sanghavi et al., 2013). In contrast, study conducted in Nigeria indicated that $71.4 \%$ of medical practitioners were aware of PV centre (Adedeji et al., 2013), similar result was obtained from India 80.9\% (Khan et al., 2013).

\section{Purpose of Reporting}

Majority of the doctors knew the purpose of ADR reporting. Based on survey results from Netherlands, $90 \%$ of medical practitioners believed that ADR reporting contribute to drug safety (Passier et al., 2009), similar outcome was reported from India 97.3\% (Desai, 2011). Another doctors from India stated that PV study will benefit patients $96 \%$ (Rishi et al., 2012a), 98\% (Ramesh and Parthasarathi, 2009), 93.6\% (Kamtane and Jayawardhani, 2012). Also large population of medical practitioners $(96 \%)$ from India stated that all the drugs available in the market are not safe (Rishi et al., 2012) and 93.6\% (Kamtane and Jayawardhani, 2012).

\section{Awareness on reporting procedure and reporting form}

Lack of awareness of the procedure and reporting form was common among the physicians interviewed. A survey from UAE revealed that $71 \%$ of the doctors do not how to report ADR(John et al., 2012) which is similar to result obtained from India 92.5\% (Sanghavi et al., 2013), Malaysia 55.6\% (Agarwal et al., 2013), Nigeria 95.1\% (Bello and Umar., 2011), Romania 68\% (Farcas et al., 2008). Also in another study from Pakistan only $9.7 \%$ are aware of the reporting system, similar results were obtained from India 6\% (Aithal et al., 2014), 44\% (Pimpalkhute et al., 2012), 43\% (Gupta and Udupa, 2011), and 43\% (Bisht et al., 2014). In contrast, studies from India have shown that $73 \%$ of doctors know the reporting system in their country (Chopra et al., 2011), 75\% (Thomas et al., 2013), 59.2\% (Kharkar and Bowalekar, 2012). With respect to the reporting form, a research from Malaysia showed that $69 \%$ of doctors said the reporting form is not available while $60.9 \%$ said it is difficult to fill.

\section{Doctors' attitude towards ADR reporting}

Four themes were identified with respect to doctors' attitude towards ADR reporting including: Obligation to report, Nature of ADR to report, Factors that influence ADR reporting and ADR due to newly marketed drug.

\section{Obligation to Report}

There was strong agreement among the medical practitioners on the need to report ADR. Based on survey from 
Romania, majority of the medical practitioners strongly agreed ADR reporting is mandatory $60.1 \%$ (Paveliu et al., 2013), similar finding was obtained from UAE $66.7 \%$ (John et al., 2012), Pakistan $80 \%$ (Iffat et al., 2014), also from several studies from India 95\% (Adhikary et al., 2013), 81\% (Sanghavi et al., 2013), 85.1\% (Kamtane and Jayawardhani, 2012), 84\% (Rishi et al., 2012b),66.2\% (Khan et al., 2013), 51\% (Bisht et al., 2014), and $80.9 \%$ (Gupta and Udupa, 2011). In contrast, only one study from India had different finding where only $15.2 \%$ of the medical practitioners believed reporting ADR is compulsory (Pimpalkhute et al., 2012).

\section{Nature of ADR to Report}

It was evident that majority of doctors do not know which type of ADR should be reported. Survey carried out in India has shown that only $10 \%$ of the doctors knew what type of ADR should be reported (Chopra et al., 2011). In another study conducted in Sweden $94 \%$ of doctors stated that severity of an ADR is the determinant of reporting (Backstrom and Mjorndal, 2006), similar findings were reported from Nigeria $77.8 \%$ (Oshikoya and Awobusuyi, 2009), Romania 50\% (Farcas et al., 2008), also in India 81.3\% (Rishi et al, 2012b), 95.6\% (Khan et al., 2013), 83.8\% (Pimpalkhute et al., 2012), 56\% (Desai et al., 2011), and $79.7 \%$ (Chatterjee et al, 2006). In several other studies doctors opined that only unusual ADR should be reported, in UAE 95\% (John et al., 2012), Nigeria 70.7\% (Oshikoya and Awobusuyi, 2009), also in India 72.1\% (Khan et al., 2013),95\% (Thomas et al., 2013), 94\% (Bisht et al., 2014), 74.4\% (Chopra et al., 2011). In contrast, only one study gave positive result as the doctors felt that all ADRs should be reported 92\% (Sanghavi et al., 2013).

\section{Factors that Influence ADR Reporting}

Based on survey findings doctors believed that many factors discourage reporting, only few felt that there some factors encourage ADR reporting.

\section{Factors that Encourage Reporting}

Research carried out in Northern Sweden indicated that certainty about ADR encourage reporting by $80 \%$ of physicians (Backstrom and Mjorndal, 2006). Survey from UAE also revealed that $96.4 \%$ of physicians said that patient safety encourage reporting (John et al., 2012).

\section{Factors that Discourage Reporting}

In a survey conducted in UAE $71 \%$ of physicians suggested that lack knowledge of reporting procedure is major reason for under-reporting (John et al., 2012). Similar findings was obtained in India 87.7\% (Chatterjee et al., 2006), 70\% (Desai et al., 2011), 95.2\% (Gupta and Udupa, 2011), and Nigeria 48.6\% (Adedeji et al., 2013). In another surveys ADR reporting was considered as time consuming, India $81.8 \%$ (Gupta and Udupa, 2011), 45\% (Sanghavi et al., 2013) and Netherland 35\% (Passier et al., 2009). In a survey conducted in Malaysia doctors felt that uncertainly about ADR discourage reporting 76.6\% (Agarwal et al., 2013), similar outcome was obtained in Sweden $75 \%$ (Backstrom and Mjorndal, 2006), Romania 40.2\% (Paveliu et al., 2013) and India 80.9\% (Gupta and Udupa, 2012), 30.9\% (Khan et al., 2013). In a study conducted in Nigeria $68.6 \%$ of doctors revealed that lack of awareness of reporting form discourage reporting (Adedeji et al., 2013), similar result was obtained from India 47\% (Aithal et al., 2014), and 49.2\% (Desai et al., 2011). In another survey carried out in Portugal $20 \%$ of physicians felt that ADR report will put their carrier at risk (Herdeiro et al., 2005), also in India 46.5\% (Kamtane and Jayawardhani, 2012).

\section{ADR due to Newly Marketed Drug}

Doctors opinion varied in terms of new drugs but majority said ADRs due to new drug should be reported, in Pakistan $85.7 \%$ (Iffat et al., 2014), Malaysia 59.3\% (Agarwal et al., 2013), India 98.7\% (Gupta and Udupa, 2011), $98.3 \%$ (Thomas et al., 2013), 65\% (Bisht et al., 2014), 35.7\% (Pimpalkhute et al., 2012). In contrast, one survey from Romania reported that only $10 \%$ of the doctors said unexpected ADR could result from new drug (Paveliu et al., 2013), similar negative finding was obtained from India where $77.9 \%$ of doctors felt that all serious ADR were known before the drug is marketed (Khan et al., 2012).

\section{Practice of Doctors towards ADR}

Practice of doctors was based on four parameters in majority of surveys conducted. These includes: Encounter with ADRs, Number of ADRs ever reported, Training on ADR reporting and Source of information to the doctors.

\section{Encounter with ADRs}

Survey data indicated that doctors' practice on ADRs reporting is generally poor because many came across ADRs but did not take any action. In a study conducted in Nigeria $64.9 \%$ of medical practitioners said they have not come across ADR (Awodele et al., 2011), similar finding was obtained in Pakistan $65.6 \%$ (Iffat bet al., 2014). However, another survey carried out in Nigeria $70.5 \%$ of physicians have encountered ADRs (Bello and Umar, 2011), 85.7\% (Adedeji et al., 2013), equivalent outcome was obtained from India 80\% (Chopra et al., 2011), 87.7\% (Chatterjee et al., 2006), 96\% (Sanghavi et al., 2013), 77\% (Kiran et al., 2014), 78.7\% (Kamtane and Jayawardhani, 2012), 86\% (Rishi et al., 2012a), 68\% (Bisht et al., 2014), 67.9\% (Pimpalkhute et al., 2012), $56.8 \%$ (Adhikary et al., 2013) and 50\% (Upadhyaya et al., 2012).

\section{Number of ADRs Ever Reported}

It is without any doubt that doctors report only small number of ADRs or not at all. Survey done in Malaysia have shown that only $5.3 \%$ of doctors ever reported ADRs (Agarwal et al., 2013), similar result was found in UAE 11\% (John et al., 2012), Romania 15\% (Fracas et al., 2008), Nigeria 5.6\% (Awodele et al., 2011), 7\% (Bello and Umar, 2011), 2\% (Oshikoya and Awobusuyi, 2009), and 29\% (Adedeji et al., 2013), also from 
India 4.4\% (Chatterjee, 2006), 2.9\% (Gupta and Udupa, 2011), 15\% (Desai et al, 2011), $15 \%$ (Kiran et al., 2014), 22.1\% (Adhikary et al., 2013), 25\% (Thomas et al., 2013), 25\% (Pimpalkhute et al., 2012), 30\% (Chopra et al., 2011), and $18.5 \%$ (Kharkar and Bowalekar, 2012). Similarly, survey from Romania revealed that $79.9 \%$ of doctors interviewed did not report any ADR (Paveliu et al, 2013), comparable result was obtained in India 77\% (Bisht et al., 2014). In contrast, article from Sweden have positive finding with $62 \%$ that have ever reported an ADR (Backstrom and Mjorndal, 2006), also an encouraging result was obtained from two articles done in India with $41 \%$ (Ramesh and Parthasarathi, 2009) and 40\% (Upadhyaya et al., 2012) reporting rate.

\section{Training on ADR Reporting}

Doctors generally agreed that they have not received adequate training to report ADRs. Survey done in UAE have shown that only $5.5 \%$ were trained on how to report ADRs (John et al., 2012), similar outcome was obtained in Nigeria where $89.6 \%$ of doctors said they need training on ADR reporting (Awodele et al., 2011), India 100\% (Sanghavi et al., 2013), 95.9\% (Adhikary et al., 2013), 80.9\% (Kamtane and Jayawardhani, 2012) and $45 \%$ (Bisht et al, 2014). In contrast one study revealed that $50 \%$ of the respondents said were taught how to report ADR during their undergraduate studies (Upadhyaya et al., 2012).

\section{Source of Information to the Doctors}

Many doctors could not identify the most appropriate source of information in PV, as majority of them did not refer to PV centre or pharmacist for information. Survey carried out in Pakistan have shown that $24 \%$ of doctors refer to internet, $33.6 \%$ seminar, $18.4 \%$ journal, $10.4 \%$ drug advert (Iffat et al., 2014), similarly, in Nigeria $41.4 \%$ book/journals, 18.3 seminars/ training, $4.4 \%$ internet (Awodele et al., 2011), also India 63\% of doctors identified internet as source of information, 65\% seminar, 69\% journal, 40\% medical books (Bisht et al, 2014), other doctors (89\%) emphasised on the role of information technology (Rishi et al, 2012b), 93.6\% (Kamtane and Jayawardhani, 2012), and 75\% (Sanghavi et al., 2013).

\section{DISCUSSION AND CONCLUSION}

ADRs and pharmacovigilance studies have become prominent and one of the most important aspect of patient care. Research in these areas in hospitals, medical and health related schools, pharmaceutical industries, and communities are of paramount importance. According to various researches reviewed KAPs of doctors were at the lowest level.

\section{Doctors' knowledge towards ADR reporting}

Knowledge is the first thing to consider when it comes to ADRs reporting. Based on the various articles reviewed, doctors' awareness on ADR reporting was inadequate. ADR reporting is a very wide concept and requires contributions of professionals from different disciplines; vast majority of the doctors interviewed did not acknowledge the contribution of other health care professionals as potential ADRs reporters (Kamtane and Jayawardhani, 2012; Oshikoya and Awobusuyi, 2009; Khan et al., 2013). It is important to note that awareness of the reporting centre is also crucial; large population of doctors were ignorant of the PV centre (Iffat et al., 2014; Thomas et al., 2013). Similarly, with regards to reporting procedure, majority of the doctors surveyed do not know how to report ADR nor they had access to the reporting card (John et al., 2012; Sanghavi et al., 2013; Bello and Umar, 2011; Agarwal et al., 2013). It is essential for doctors to possess wide knowledge on ADRs and ADR reporting procedure, and also able to assess the causal relationship between the identified disorder and the suspected drug. It is clear that knowledge on ADR reporting was not given much consideration during doctors training as majority of them interviewed had advocated for the need of training on ADR reporting (Awodele et al., 2011; Kamtane and Jayawardhani, 2012; Sanghavi et al., 2013).

\section{Doctors' attitude towards ADR reporting}

Doctors' attitudes towards ADR reporting was quite discouraging, surveys carried out reported that large percentage of doctors believed that only serious ADRs should be considered more important or they don't even know what type of ADR to report (Backstrom and Mjorndal, 2006; Rishi et al., 2012b; Oshikoya and Awobusuyi, 2009). It is important to acknowledge that less serious and unusual ADRs are also important because they might serve as a clue to the possibility of fatal ADR to occur in the future. The factors identified by doctors as obstacles in reporting ADR should be dealt with immediately; they include lack of knowledge of reporting procedure, time consumption, uncertainty about the ADR, availability of the reporting form, and legal problem (Chatterjee et al., 2006; Gupta and Udupa, 2011;Agarwal et al., 2013; Adedeji et al., 2013; Kamtane and Jayawardhani, 2012). However, since most of the doctors considered ADR reporting as professional obligation they should be able to overcome most of the obstacles stated as no part of patient care seems to be friendly (Iffat et al., 2014; Sanghavi et al., 2013; Paveliu et al., 2013). Based on this reason, it can be established that awareness lecture is urgently needed to improve the doctors' attitude towards ADR reporting. Further research should be conducted to evaluate doctors' opinions with respect to ADR monitoring.

\section{Doctors' practice towards ADR reporting}

According to various research outcomes, doctors' practice towards ADR reporting was far below expectation. Meanwhile, the rate at which ADRs were reported to the relevant regulatory authority was quite overwhelming; greater part of the doctors that came across ADR either sent few reports or did not reported at all (Chatterjee et al., 2006; Agarwal et al., 2013; Oshikoya and Awobusuyi, 2009; John et al., 2012). It was evident that hospitals managements, pharmaceutical companies, drug 
regulatory agencies did not made significant contribution towards educating doctors on ADR monitoring and reporting. Survey conducted in UAE revealed that only $5.5 \%$ of doctors received training on ADR reporting (John et al., 2013). This have suggested the urgent need for all stake holders to come together to ensure proper implementation of PV program. It is imperative for doctors to identify hospital drug and therapeutic committee, PV centres and pharmacist as the major source of drug safety information. Further interventional studies should be carried out in order to improve doctors' practice which the major aim of PV. It is recommended that $\mathrm{PV}$ program can be improve by establishing more ADRs monitoring centres, including PVstudy in medical, pharmacy and nursing students curriculum, involvement of other health care workers like physiotherapist, medical laboratory scientist and medical health record in ADRs reporting. Providing legal backing for ADRs reporting and public awareness campaign are also very essential.

Several articles reviewed have established that the major challenge in health care delivery services especially medicine related issues are ADRs; doctors knowledge, attitudes and practices were generally poor. Drug regulatory authorities, pharmaceutical companies, healthcare professionals and academia must be proactive in ADRs detection, documentation and reporting. It has become unconditionally essential for WHO, national and hospital based pharmacovigilance centres to provide the necessary materials for ADRs reporting and to make the reporting procedure easy across the tertiary, secondary and primary health care centres worldwide.

\section{Limitation of the Study}

In the course of review several obstacles were encountered but the main limiting factor in this study is that the findings cannot be generalised to all doctors. This is because many countries were not represent in the review, also some articles full text were not accessible. Lack of funding as well played a role because few articles came across needed to be purchased online. Another limitation is heterogeneous nature of some few surveys that differs from others in terms of study design.

\section{ACKNOWLEDGEMENT}

No funding is obtained to conduct the study. Authors possess no any conflict of interest.

\section{REFERENCES}

Adedeji WA, Ibrahem WA, Fehintola FA. Attitude and Practice of Doctors toward Adverse Drug Reactions (ADRs) Reporting In A Nigerian Tertiary Health Facility. Ann Ibd Pg Med, 2013; 1(2): 77-80. Available from http://www.ncbi.nlm.nih.gov/pmc/articles/PMC4111063/pdf/AIPM-1177.pdf (Accessed on 10/7/2014)

Adhikary J, Bhandare B, Adarsh E, Satyanarayana V. A Study to Assess Knowledge, Attitude and Practice of Adverse Drug Reaction Reporting among Physicians in a Tertiary Care Hospital. Journal of Evolution of Medical and Dental Sciences, 2013: 2 (9): 1027- 1034. Available from http://www.jemds.com/data_pdf/1_jyothirmay-
A\%20STUDY\%20TO\%20ASSESS\%20KNOWLEDGE.pdf $10 / 8 / 2014)$

Agarwal R, Daher AM, Ismail NM. Knowledge, Practices and Attitudes Towards Adverse Drug Reaction Reporting by Private Practitioners from Klang Valley in Malaysia. Malays J Med Sci, 2013; 20(2): 52-61. Available from http://www.ncbi.nlm.nih.gov/pmc/articles/PMC3744000/pdf/mjms-20-2052.pdf (Accessed 10/8/2014)

Aithal S, Hooli TV, Varun HV. Knowledge and Attitude about Adverse Drug Reaction Reporting among Doctors at a Tertiary Care Hospital. International Journal of Pharma \& Bio Sciences, 2014; 5 (1): 108-113. Available from http://www.ijpbs.net/cms/php/upload/2976_pdf.pdf (Accessed 10/8/2014)

Awodele O, Akinyede A, Adeyemi OA, Awodele DF. Pharmacovigilance amongst doctors in private hospitals in Lagos West Senatorial District, Nigeria. Int J Risk Saf Med, 2011; 23 (4): 217 226.

Backstrom M, Mjorndal T. A small economic inducement to stimulate increased reporting of adverse drug reactions - a way of dealing with an old problem? Eur J Clin Pharmacol, 2006; 62: 381-385. Available from

http://download.springer.com/static/pdf/527/art\%253A10.1007\%252Fs002 28-005-0072-

0.pdf?auth66=1410888303_9c50afa1bcdb81d31e9a9e6aeda2ba3e\&ext=.p df (Accessed 10/7/2014)

Bello SO, Umar MT. Knowledge and attitudes of physicians relating to reporting of adverse drug reactions in Sokoto, North-Western Nigeria. Annals of African Medicine. 10 (1); 2011: 13-18. Available from http://www.researchgate.net/publication/49826701_Knowledge_and_attitu des_of_physicians_relating_to_reporting_of_adverse_drug_reactions_in_S okoto_north-western_Nigeria (Accessed 10/8/2014)

Bisht M,Singh S, Dhasmana DC. Effect of Educational Intervention on Adverse Drug Reporting by Physicians: A CrossSectional Study. ISRN Pharmacology, 2014; Article ID 259476. Available from file:///C:/Users/User/Downloads/259476.pdf (Accessed 11/8/2014)

Chatterjee S, Lyle N, Ghosh S. A survey of the knowledge, attitude and practice of adverse drug reaction reporting by clinicians in eastern India. Drug Saf, 2006; 29(7): 641-642. (Accessed 11/8/2014)

Chopra D, Wardhan N, Rehan HS. Knowledge, attitude and practices associated with adverse drug reaction reporting amongst doctors in a teaching hospital. The International Journal of Risk \& Safety In Medicine, 2011; 23(4): 227-232. Available from http://web.b.ebscohost.com/ehost/pdfviewer/pdfviewer?vid=9\&sid=00746 7f1-7730-4558-a2f0-abb089b9b06c\%40sessionmgr112\&hid=128 (Accessed 11/8/2014)

Desai CK, Iyer G, Panchal J, Shah S, Dikshit RK. An evaluation of knowledge, attitude, and practice of adverse drug reaction reporting among prescribers at a tertiary care hospital. Perspect Clin Res, 2011; 2 (4): 129-136. Available from http://www.ncbi.nlm.nih.gov/pmc/articles/PMC3227330/ (Accessed on 1/9/2014)

Edward IR, Aronson JK. Adverse drug reactions: definitions, diagnosis and management. Lancet, 2000; 356(9237): 1255-1259. Available from http://www.scribd.com/doc/22293073/Adverse-DrugReactions-Definitions-Diagnosis-And-Management (Accessed 12/8/2014)

Farcas, A, Macavei C, Bojita M. Physicians' attitude towards voluntary reporting of adverse drug reactions. FARMACIA, 2008; 56 (5): 563-570. http://www.revistafarmacia.ro/20085/issue52008art12.doc (Accessed 12/8/2014)

Gray J. Bill would force drug makers to give customers data on risk. The New York Times. July 25, 1996: A11.

Gupta P, Udupa A. Adverse Drug Reaction Reporting and Pharmacovigilance: Knowledge, Attitudes and Perceptions amongst Resident Doctors. J Pharm Sci Res, 2011; 3(2): 1064-1069. Available from

http://www.jpsr.pharmainfo.in/Documents/Volumes/Vol3Issue02/jpsr\%20 03110205.pdf (Accessed 12/8/2014) 
Harmark L, van Grootheest AC. Pharmacovigilance: methods, recent developments and future perspectives. Eur J Clin Pharmacol, 2008; 64:743-752. Available

from http://download.springer.com/static/pdf/836/art\%253A10.1007\%252Fs002 28-008-0475-

9.pdf?auth66=1410972179_7730691fe6dc6eed698d8e4eb37d978d\&ext=. pdf

Herdeiro MT, Figueiras A, Polonia J, Gestal-Otero JJ. Physicians' Attitudes and Adverse Drug Reaction Reporting: A CaseControl Study in Portugal. Drug Safety, 2005; 28 (9): 825-833. Available from http://phdtree.org/pdf/16296648-physicians-attitudes-and-adversedrug-reaction-reporting-a-case-control-study-in-portugal/

http://www.lareb.nl/LarebCorporateWebsite/media/publicaties/2009-

3_DS_ADR_GP.pdf (Accessed 10/8/2014)

Iffat W, Shakeel S, Rahim N, Anjum F, Neesar S, Ghayas S. Pakistani physicians' knowledge and attitude towards reporting adverse drug reactions. African Journal of Pharmacy and Pharmacology, 2014; 8 (14): $\quad 379-385 . \quad$ Available from http://www.academicjournals.org/article/article1398412633_Iffat\%20et\%2 0al.pdf (Accessed 10/8/2014)

International Society of Drug Bulletins (ISDB), Berlin Declaration on Pharmacovigilance, January, 2005. Available from http://www.isdbweb.org/documents/uploads/Declaration/Berlin_Declarati on_Berlin\%20Engl.pdf (Accessed 11/8/2014)

John LJ, Arifulla M, Cheriathu J, Sreedharan J. Reporting of Adverse Drug Reactions: a study among Clinicians. Journal of Applied Pharmaceutical Science, 2012; 2 (6): 135-139. Available from http://www.japsonline.com/admin/php/uploads/518_pdf.pdf (Accessed $10 / 8 / 2014)$

Kachhadiya R, Kumar A, Bhatia RK. Prevalence of medication errors across the world. International Journal of Pharmaceutical Research, 2009; 1(3):21-34. Available from http://www.ijpronline.com/ViewArticleDetail.aspx?ID=36 (Accessed $10 / 8 / 2014$ )

Kamtane RA, Jayawardhani V. Knowledge, attitude and perception of physicians towards adverse drug reaction (ADR) reporting: a pharmacoepidemiological study. Asian J Pharm Clin Res, 2012; 5(3): 210 214. Available from http://www.ajpcr.com/Vol5Suppl3/1231.pdf (Accessed 10/8/2014)

Khan SA, Goyal C, Chandel N, Rafi M. Knowledge, attitudes, and practice of doctors to adverse drug reaction reporting in a teaching hospital in India: An observational study. Journal of Natural Science, Biology, and Medicine, 2013; 4(1): 191-196. Available from (Accessed $11 / 8 / 2014)$

Kharkar M, Bowalekar S. Knowledge, attitude and perception/practices (KAP) of medical practitioners in India towards adverse drug reaction (ADR) reporting. Perspect Clin Res, 2012; 3(3): 9094.

Kiran LJ, Shivashankaramurthy K G, Bhooma S, Dinakar Kr. Adverse drug reaction reporting among clinicians in a teaching hospital in South Karnataka. Sch Journ App Med Sci, 2014; 2(1D):399-403. Available from http://saspublisher.com/wp-content/uploads/2014/03/SJAMS21D399-403.pdf

Kohn L, Corrigan J, Donalson M. Eds to err is Human: Building safer Health System. Washington, DC: Institute of Medicine. 2000. Available from http://neurosurgery.ucsf.edu/tl_files/NS_Main/QI/IOM_To\%20Err\%20is \%20Human.pdf (Accessed 11/8/2014)

Lazarou J, Pomeranz BH, Corey PN. Incidence of adverse drug reactions in hospitalized patients. A meta-analysis of prospective studies. JAMA, 1998; 279(15): 1200-1205. Available from http://www.ncbi.nlm.nih.gov/pubmed/9555760 (Accessed 10/8/2014)

Oshikoya KA, Awobusuyi JO. Perceptions of doctors to adverse drug reaction reporting in a teaching hospital in Lagos, Nigeria. BMC Clin Pharmacol, 2009; $\quad 9 \quad$ (14). Available from http://www.biomedcentral.com/content/pdf/1472-6904-9-14.pdf (Accessed on $1 / 9 / 2014$ )
Passier A, Napel MT, van Grootheest K, van Puijenbroek E. Reporting of Adverse Drug Reactions by General Practitioners. Drug Saf, 2009; $32 \quad$ (10): 851-858. Available from http://link.springer.com/article/10.2165\%2F11314490-000000000-00000 (Accessed on 30/8/2014)

Patel A, Ganguly B. Analysis of Dose Calculation of Medicines Prescribed in Pediatric Age Group. International Journal of Pharmaceutical Research, 2010; 2(4): 21-25.

Paveliu MS, Bengea-Luculescu S, Toma M, Paveliu SF. Perception on Adverse Drug Reaction Reporting by Physicians Working in Southern Romania. Journal of Clinical Medicine, 2013; 8(1): 17-25. Available from http://www.maedica.org/articles/2013/1/2013_Vol8\%2811\%29_No1_pg1 7-25.pdf (Accessed 11/8/2014)

Phillips KA, Veenstra DL, Oren E, Lee JK, Sadee W. potential role of pharmacogenomics in reducing adverse dug reaction. JAMA, 2001; 286 (18): 2270- 2279. Available from http://jama.jamanetwork.com/bypdf (Accessed 10/8/2014)

Pimpalkhute SA, Jaiswal KM, Sontakke SD, Bajait CS, Gaikwad A. Evaluation of awareness about pharmacovigilance and adverse drug reaction monitoring in resident doctors of a tertiary care teaching hospital. Indian J Med Sci, 20121; 66 (3 \& 4): 55-61. Available from

http://web.b.ebscohost.com/ehost/pdfviewer/pdfviewer?vid=5\&sid=00746 7f1-7730-4558-a2f0-abb089b9b06c\%40sessionmgr112\&hid=128

Ramesh M, Parthasarathi G. Adverse drug reactions reporting: attitudes and perceptions of medical practitioners. Asian J Pharm Clin Res, 2009; 2 (2): $\quad 10-14$. Available from http://www.ajpcr.com/Vol2Issue2/184.pdf (Accessed 10/8/2014)

Rishi RK, Patel RK, Bhandari A. Opinion of physicians towards Adverse Drug Reaction reporting Result of pilot study. Journal of Community Nutrition and Health, 2012b; 1 (1): 25-29. Available from URL:http://jenh.in/download/isse1/6.\%20Rakesh.pdf

(Accessed 10/8/2014

Rishi RK, Patel RK, Bhandari A. Under Reporting of ADRs by Medical Practitioners in India - Results of Pilot Study. Advances in Pharmacoepidemiol and Drug Saf, 2012a; 1 (3): 1-3. Available from http://omicsgroup.org/journals/under-reporting-of-adrs-by-medicalpractitioners-in-india-results-of-pilot-study-2167-1052.1000112.pdf (Accessed 10/8/2014)

Salam A, Haque M, Islam MZ, Rahman NIA, Helali AM, Muda TFMBT, Yousuf R, Yesmin F, Rahman Z, Alattraqchi AG. Addressing rational prescribers through pharmacology and therapeutics course work of MBBS syllabus in Bangladesh. International Research Journal Pharmacy, 2013; 4 (7): 60-63. Available from http://dx.doi.org/10.7897/22308407.04713/pdf (Accessed 10/8/2014)

Sanghavi DR, Dhande PP, Pandit VA. Perception of pharmacovigilance among doctors in a tertiary care hospital: Influence of an interventional lecture. Int J Risk Saf Med, 2013; 25 (4): 197-204. Available from http://web.b.ebscohost.com/ehost/pdfviewer/pdfviewer?vid=6\&sid=00746 7f1-7730-4558-a2f0-abb089b9b06c\%40sessionmgr112\&hid=128 (Accessed 10/8/2014)

Shailesh N, Ranjana K, Kumar VS, Satish B. Impact of Educational Intervention on Knowledge, Attitude and Practice of Pharmacovigilance among Medical Graduates of Rural Tertiary Care Teaching Hospital Of Central India. Mintage journal of Pharmaceutical \& Medical Sciences, 2013; 2(2): 51-54. Available from http://mintagejournals.com/index_htm_files/123.pdf

Tabali M, Jeschke E, Bockelbrink A, Witt CM, Willich SN, Ostermann T, Matthes H. Educational intervention to improve physician reporting of adverse drug reactions (ADRs) in a primary care setting in complementary and alternative medicine. BMC Public Health, 2009; 9(274). Available from http://www.biomedcentral.com/content/pdf/14712458-9-274.pdf (Accessed 10/7/2014)

Talbot JC, Nilsson BS. Pharmacovigilance in the pharmaceutical industry. Br J Clin Pharmacol, 1998; 45(5): 427-31. Available from http://onlinelibrary.wiley.com/doi/10.1046/j.13652125.1998.00713.x/pdf (Accessed 10/7/2014) 
Thomas TM, Udaykumar P, Scandashree K. Knowledge, attitude and practice of adverse drug reaction reporting among doctors in a tertiary health care centre in South India. Int J Pharmacol Clin Sci, 2013; 2(3): 82-88. Available

from http://www.ijpcs.net/uploads/1/0/3/4/10341868/ijpcs-0023-2013.pdf

Upadhyaya P, Seth V, Moghe VV, Sharma M, Ahmed M. Knowledge of adverse drug reaction reporting in first year postgraduate doctors in a medical college. Ther Clin Risk Manag, 2012; 8: 307-312. Available from file:///C:/Users/User/Downloads/TCRM-31482knowledge-of-adverse-drug-reaction-reporting-in-first-year-p_061812.pdf (Accessed 10/7/2014)

van Grootheest K, de Jong-van D. Patients' role in reporting adverse drug reactions. Expert Opin Drug Saf, 2004; 3(4): 363-368.

van Grootheest K, Olsson S, Couper M. Pharmacists' role in reporting adverse drug reactions in an international perspective. Pharmacoepidemiol Drug Saf, 2004; 13(7):457-464. Available from http://onlinelibrary.wiley.com/doi/10.1002/pds.897/abstract;jsessionid=FE A1D0E08859B298C5701A963C98D8B5.f01t03 (Accessed on 1/7/2014)

World Health Organization (WHO) Definitions. WHO International Drug Monitoring: The role of national centres: Tech Rep Ser.1972 no. $498 . \quad$ Available from http://www.who.int/medicines/areas/quality_safety/safety_efficacy/trainin gcourses/definitions.pdf (Accessed 10/7/2014)
World Health Organization (WHO). International Drug Monitoring: The Role of Hospital; Geneva, Switzerland: WHO; 1969. Technical Report Series No. 425. Available from http://whqlibdoc.who.int/trs/WHO_TRS_425.pdf (Accessed 10/7/2014)

World Health Organization (WHO). Safety of Medicines. A guide to detecting and reporting adverse drug reactions. Why health professionals need to take action. Geneva World Health Organization. 2002 Available http://whqlibdoc.who.int/hq/2002/WHO_EDM_QSM_2002.2.pdf (Accessed 10/7/2014)

\section{How to cite this article:}

Abdullahi Rabiu Abubakar, Nordin Bin Simbak, Mainul Haque. A Systematic Review of Knowledge, Attitude and Practice on Adverse Drug Reactions and Pharmacovigilance among Doctors. J App Pharm Sci, 2014; 4 (11): 117-127 